UDC 519.6

\title{
Variational assimilation of temperature for the model of hydrodynamics of the Baltic Sea: the solution of the open boundary problem *
}

\author{
V.I. Agoshkov**, T.O. Sheloput*** \\ Institute of Numerical Mathematics of the Russian Academy of Sciences; Moscow State University, \\ Moscow, Russia \\ Institute of Numerical Mathematics of the Russian Academy of Sciences
}

The problem of modeling water areas with «liquid» (open) lateral boundaries is discussed. The mathematical model of the Baltic Sea circulation, developed in INM RAS, is considered. It is based on the system of thermohydrodynamic equations in the Boussinesq and hydrostatic approximations. The splitting method is used for time approximation in the model. Temperature (salinity) assimilation problem is investigated and solved for reconstructing unknown functions in boundary conditions at open boundaries. The domain decomposition method was used for acceleration of the assimilation procedure.

Keywords: variational data assimilation; inverse problems; open boundaries; numerical methods; adjoint equations

Introduction. In problems of geophysical hydrodynamics, the problem arises of setting boundary conditions on «liquid» (open) boundaries. Especially often, this problem is faced by developers of regional models and models of marginal seas. From the way boundary conditions are set at open boundaries, the result depends directly on both long-term calculations and operational forecasting problems, and if the boundary conditions are improper, the fields of the hydrophysical parameters (temperature, level, etc.) obtained as a result of the calculation can be distorted or «contaminated» by oscillations that are not observed in nature.

There are various approximations that can be used to specify the boundary conditions on the «liquid» boundaries. Sometimes the approximation of the «material» boundary is used, the «liquid» boundary is considered mobile, and the condition of «non-flow» is specified on it. Another common technique is the use of averaged data on flows through an open boundary [17]. However, this method does not take into account the variability of water exchange (related, for example, to the nature of atmospheric circulation). Sometimes it is possible to carry out preliminary calculations throughout the entire oceans area on a coarse grid, and to use the obtained data as boundary conditions on the «liquid» boundary. Despite the widespread use of this approach, such data are approximate and often

\footnotetext{
* The research is done with the financial support from the RSF (Grant 14-11-00609, within which the numerical experiments were carried out) and the RFBR (grant 16-01-00548, within which the investigation of the formulated problems was carried out).

** E-mail: agoshkov@inm.ras.ru.

*** E-mail: sheloput@phystech.edu
} 
incompatible with the regional model. The most promising of existing methods is the use of assimilation of observational data (if the latter are presented).

The choice of the form of recording the boundary conditions on the «liquid» boundaries is also a matter of debate. In some regional models, radiation conditions are set on open boundaries, which are realized in accordance with the scheme proposed in [5]. In the paper [7], the following formulation of the boundary conditions on the «liquid» boundaries occurs: the Dirichlet conditions at the points of the «inward fluxes», the «point», and the radiation conditions at the remaining points. There are other formulations [8]. The setting of the boundary conditions depends to a large extent on the simplifications used. In particular, a lot of papers have been devoted to models based on the system of «shallow water» equations, in which inverse problems are investigated $[6,12,13]$. The situation becomes more complicated in the case of models based on the three-dimensional Navier-Stokes equations [4].

In $[1,2]$, an alternative approach to the specification of boundary conditions was used. To approximate the model with respect to time, the splitting method was used [15, 16], which allowed us to consider the problem of data assimilation for a nonlinear model of hydrothermodynamics on each time interval, solving consistently simpler assimilation problems, using observational data corresponding to changing variables [11]. In [1], a class of inverse problems on «boundary functions» defining boundary conditions on «liquid boundaries» was posed and solvability of a number of problems from this class was investigated, and algorithms for their numerical solution based on variational assimilation of observational data were proposed.

In this paper, one of these sub-problems is discussed: the problem of assimilation of temperature data, and the results of numerical experiments for the Baltic Sea and the Gulf of Finland are shown, illustrating the effectiveness of the method proposed in [1].

The mathematical model, splitting method, and the problem of data assimilation. The mathematical model of the hydrothermodynamics of the Baltic Sea, developed in the Institute of Numerical Mathematics of the Russian Academy of Sciences (INM RAS), is considered [9, 10, 14]. The model is based on the system of equations of hydrothermodynamics in the Boussinesq approximation and hydrostatics [15]. To approximate the model over time, the splitting method [11] (the weak approximation method) is used. A complete system of equations, boundary and initial conditions can be found in [1].

Suppose that on the segment $[0, \bar{t}]$ the grid: $0=t_{0}<t_{1}<\ldots<t_{J}=\bar{t}$ is introduced. The solution of the complete problem on the $j$-th time step is approximated by solving the following subproblems (steps of the splitting method). In step 1 we consider equations of the «shallow water» type for integral velocities and level functions, then corrections are sought for three- dimensional velocities. The problem of convection-diffusion for temperature is considered in step 2, and for salinity in the third step. At the end of each of these steps, corrections are made to the velocities associated with changes in the temperature and salinity. The problem for velocities is solved in step 4, in which the influence of fourth-order operators is taken into account, and in step 5, a system for a three-dimensional velocity field with operators of no higher than second order is solved. The formulations of these sub-problems 
can be found in $[1,2]$. After solving the problems at all steps of the splitting method, the obtained parameter vector - velocities, temperature, salinity, sea level - is taken as an approximate solution of the problem on the $j$-th time interval. Note that in this case the temperature T only changes in step 2, which means that the problem of temperature data assimilation should be solved exactly in this step. The temperature field is corrected, minimizing the difference between the calculated and observed temperature at the least-square sence.

Thus, at each time step in step 2 of the splitting method, the inverse problem for convectiondiffusion heat equations is solved to restore the additional unknown function in the boundary conditions at the open boundary. It is assumed that the observational data $T_{o b s}$ given on that part of the open boundary, where the flow vector is directed into the simulated water area. The inverse problem was investigated in [2], where it is reformulated as the problem of minimizing the functional:

$$
J_{\alpha} \equiv \frac{\alpha}{2} \int_{t_{j-1}}^{t_{j}} \int_{\Gamma} m_{w, o p} U_{n}^{(-)}\left(d_{T}-d_{T}^{(0)}\right)^{2} d \Gamma d t+\frac{1}{2} \int_{t_{j-1}}^{t_{j}} \int_{\Gamma} \chi_{o b s}\left(T-T_{o b s}\right)^{2} d \Gamma d t \rightarrow \inf _{d_{T}},
$$

where $\alpha>0$ is a small regularization parameter, $d_{T}$ is an additional unknown, $\Gamma$ is the boundary of the three-dimensional region (water area), $m_{w, o p}, \chi_{o b s}$ are the characteristic functions of regions where additional unknowns and observations are given, respectively. An iterative algorithm was proposed to solve the minimization problem [2].

The results of numerical experiments. To test the effectiveness of the proposed methodology, a number of numerical experiments were carried out, the results of which are presented and discussed in this section.

The idea of the first series of experiments was proposed to test the effectiveness of the program on model data. The results of the experiments are given and discussed below.

Initially, a preliminary calculation was carried out for 12 model hours in the entire Baltic Sea area. As parameters of the model (the coefficients of diffusion, the right-hand side of the equation («forcing»), the initial data and the velocity vector) the corresponding parameters and results of the calculation of the direct model of hydrothermodynamics of the Baltic Sea developed at INM RAS were chosen.

Further from the area of the Baltic Sea the Gulf of Finland was separated. The result of the preliminary calculation was used to specify «observational data» on the «liquid» boundary (the interface between the Baltic Sea and the Gulf of Finland). For the Gulf of Finland area, calculations were made on a smaller grid with and without using the assimilation procedure discussed in this article. After that, the results of the calculations were compared with the results of preliminary calculations (in particular, the comparison of surface temperatures was performed). Note that only the temperature at the boundary was assimilated, while the results for the surface temperature are compared.

Fig. 1 a) shows the difference between the temperature field at the final time instant on the surface obtained in the calculation without using the assimilation algorithm and the field obtained in 
the preliminary calculation («observed»). The results can be compared with the results shown in fig. $1 \mathrm{c}$ ), which shows the temperature difference between the field obtained by calculation with using the algorithm and the same assimilation «observed» field. As can be seen from these figures, the algorithm corrects the boundary conditions so that the surface temperature becomes closer to the «observed» temperature, and the temperature is «corrected» by an amount less than a degree modulo, and to a greater extent near the «liquid» boundary itself.

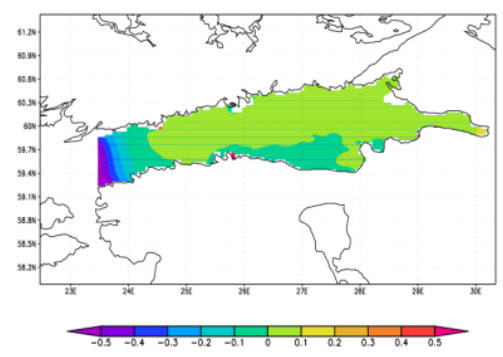

a)

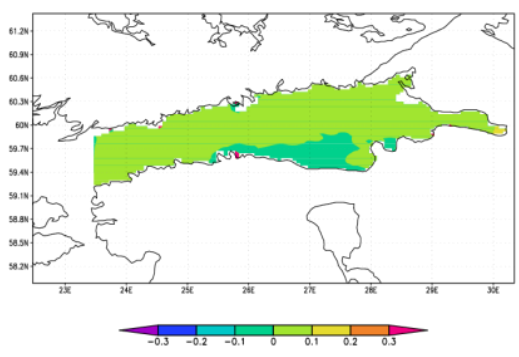

c)

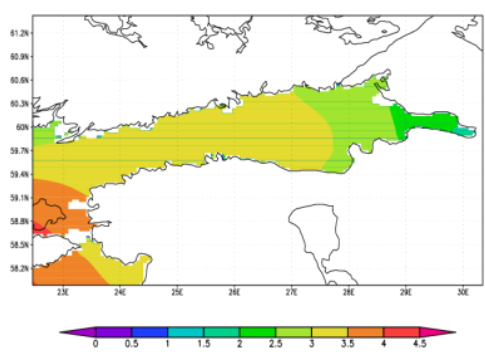

b)

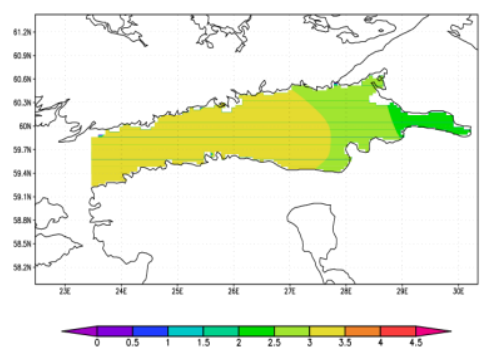

d)

Fig. 1. The experimental results: a) the difference between the initial (without the use of the assimilation algorithm) and the «observed» temperature fields; b) the «observed» temperature field;

c) the difference between the final (after using the assimilation algorithm) and the «observed» temperature fields; d) a finite temperature field

Fig. 1 b) and 1 d) show the comparison between the «observed» temperature field and the temperature field obtained at the last iteration of the assimilation algorithm (at the final instant of time on the surface).

The second series of experiments were carried out to evaluate the efficiency of assimilation of temperature profiles at the open boundary in the model of hydrothermodynamics of the Baltic Sea.

Fig. 2 a) shows the temperature field $\mathrm{T}_{\text {obs }}[10]$ (a cross section between the North Sea and the Baltic Sea, the position of the boundary itself can be seen in fig. 3 a)). Fig. 2 b) and 2 d) shows the temperature fields at the time point of 14 model days from the beginning of calculation without and with using the assimilation procedure. In the blue color, points are marked where the velocity vector of the water flow is directed into the water area (from the North Sea to the Baltic Sea). The 
corresponding surface temperature distributions are shown in fig. 3 b), 3 c), 3 d). The temperature field in fig. $3 \mathrm{~d}$ ) is closer to that shown in fig. $3 \mathrm{~b}$ ) than received without the using of assimilation.

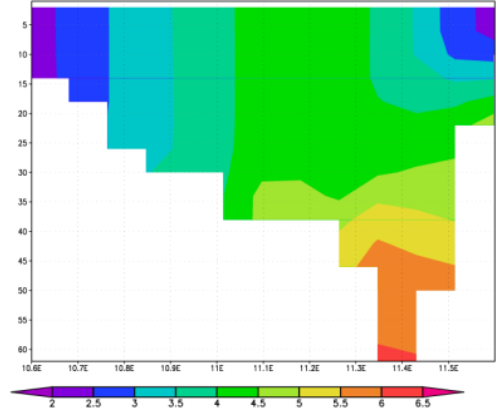

a)

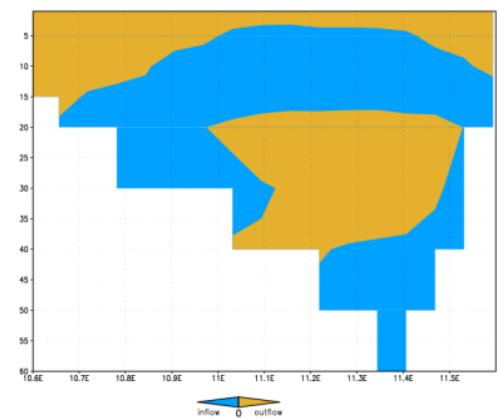

c)

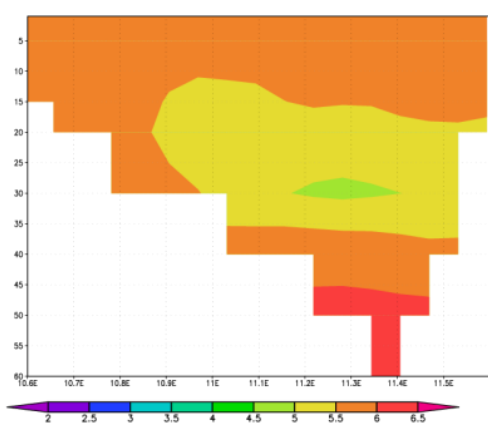

b)

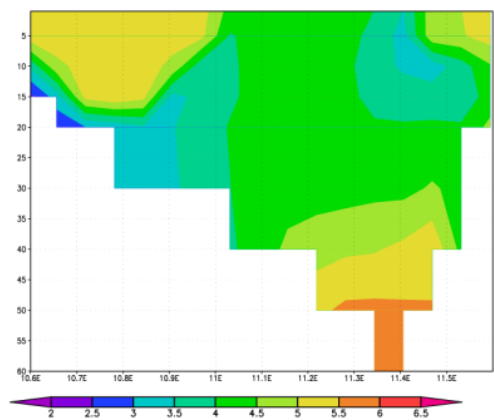

d)

Fig. 2. a) «observed» (reanalysis); b) calculation without assimilation; c) points of incoming flows; d) calculation with assimilation

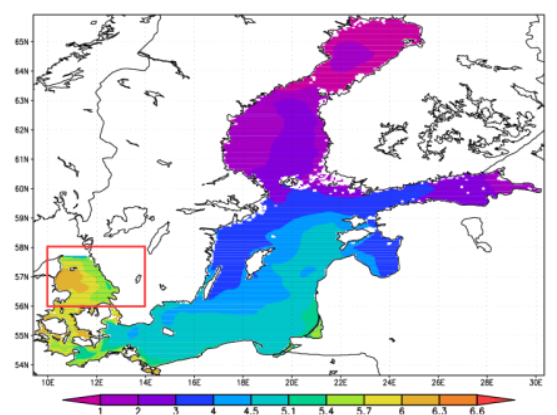

a)

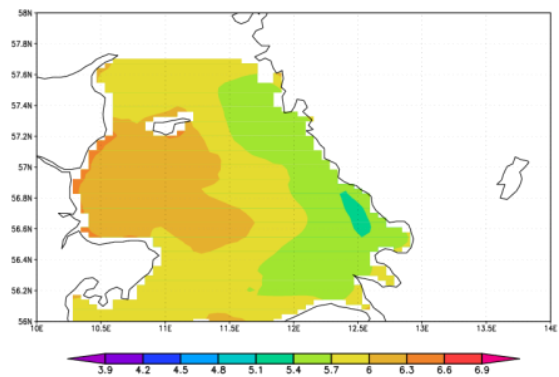

c)

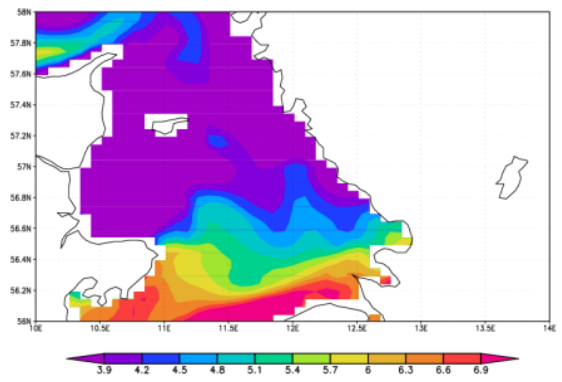

b)

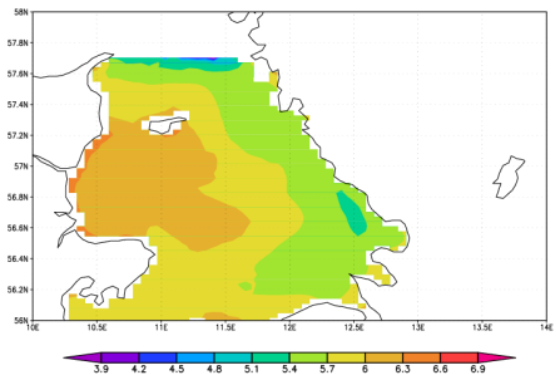

d) 
Fig. 3. a) the simulated zone and the region near the open boundary (red rectangle); b) «observed» (reanalysis); c) calculation without assimilation; d) calculation with assimilation

The underlying numerical model is based on parallel algorithms, but the assimilation procedure itself is consistent. To speed up the calculations, the domain decomposition method was used. In this case, the computational errors were insignificant and did not affect the quality of the results obtained.

\section{References}

1. Agoshkov, V.I. Statement and study of some inverse problems in modelling of hydrophysical fields for water areas with 'liquid' boundaries / V.I. Agoshkov // Russ. J. Numer. Anal. Math. Modelling. - 2017. - V.32, No. 2. - pp.73-90.

2. Agoshkov, V.I. The study and numerical solution of some inverse problems in simulation of hydrophysical fields in water areas with 'liquid' boundaries / V.I. Agoshkov, T.O. Sheloput // Russ. J. Numer. Anal. Math. Modelling. - 2017. - V.32, No.3. - pp. 147-164.

3. Agoshkov, V.I. The study and numerical solution of the problem of heat and salinity transfer assuming 'liquid' boundaries / V.I. Agoshkov, T. O. Sheloput // Russ. J. Numer. Anal. Math. Modelling. - 2016. - Vol.31, No. 2. - pp. 71-80.

4. Gejadze, I. Yu. Open Boundary Control Problem for Navier-Stoces Equations Including a Free Surface: Data Assimilation / I. Yu. Gejadze, G. J. M. Copeland, I. M. Navon // Computers and Mathematics with Applications. - 2006. - V.52. - pp. 1269-1288.

5. Marchesiello, P. Open boundary conditions for long-term integration of regional oceanic models / P. Marchesiello, J. C. McWilliams, A. Shchepetkin // Ocean Modelling. - 2001. - No. 3. pp. 1-20.

6. Ngodock, H. On the direct assimilation of along-track sea-surface height observations into a free-surface ocean model using a weak constraints four-dimensional variational (4D-Var) method / H. Ngodock, M. Carrier, I. Souopgui, S. Smith, P. Martin, P. Muscarella, G. Jacobs // Quarterly Journal of the Royal Meteorological society. - 2016. - V.142. - pp. 1160-1170.

7. Semenov, E. V. Problems of Operational Data Assimilation for Marginal Seas / E. V. Semenov, E. V. Mortikov // Izvestiya, Atmospheric and Oceanic Physics. - 2012. - Vol. 48, No. 1. pp. 74-85.

8. Temam R. Open Boundary Conditions for the Primitive and Boussinesq Equations / R. Temam, J.Tribbia // Journal of the Atmospheric Sciences. - 2003. - V.60. - pp. 2647-2660.

9. Zalesny V. The Baltic Sea circulation modelling and assesment of marine pollution / V. Zalesny, A. Gusev, S. Chernobay, R. Aps, P. Kujala, J.Rytkönen, R. Tamsalu // Russ. J. Numer. Analysis and Math Modelling. - 2014. - V.29, No. 2. - pp. 129-138.

10. Baltic Sea Physics Reanalysis from SMHI (1989-2014) // Copernicus marine environment monitoring service. URL: http://marine.copernicus.eu (date of access: 13.03.2017).

11. Agoshkov, V.I. Metody resheniya obratnykh zadach i zadach variatsionnoy assimilyatsii dannykh nablyudeniy v problemakh krupnomasshtabnoy dinamiki okeanov i morey. Moscow: INM RAS, 2016. - 192 p.

12. Agoshkov, V. I. Issledovaniye i chislennoye resheniye odnoy obratnoy zadachi modelirovaniya tsirkulyatsii $\mathrm{v}$ akvatoriyakh $\mathrm{s}$ «zhidkimi» granitsami / V.I. Agoshkov, D.S. Grebennikov, T.O. Sheloput // Mathematical notes of NEFU. - 2015. - V. 22, No. 2. - P. 3-15. 
13. Dementieva, E. B. Vosstanovleniye granichnoy funktsii po dannym nablyudeniy dlya zadachi rasprostraneniya poverkhnostnykh voln v akvatorii s otkrytoy granitsey / E. V. Dementieva, E. D. Karepov, V. In . Shaidurov// Siberian Journal of Industrial Mathematics. - 2013. - V. 16, No. 1. - pp. 10-20.

14. Diansky, N.A. Sigma-model' global'noy tsirkulyatsii okeana i yeye chuvstvitel'nost' k variatsiyam napryazheniya treniya vetra / N.A. Diansky, A.V. Bagno, V.B. Forestry// Physics of the atmosphere and ocean. - 2002. - V. 38, No. 4. pp. 537-556.

15. Marchuk, G. I. Matematicheskiye modeli v geofizicheskoy gidrodinamike i chislennyye metody ikh realizatsii/ G.I. Marchuk, V.P. Dymnikov, V.B. Forestry. - Gidrometeoizdat, 1987. -296 p.

16. Marchuk G.I. Metody vychislitel'noy matematiki. - Moscow: Nauka, 1989. - 608 p.

17. Chernov, I. A. Chislennoye modelirovaniye krupnomasshtabnoy dinamiki Belogo morya / I. A. Chernov, A. V. Tolstikov // Proceedings of the Karelian Research Center of the Russian Academy of Sciences. - 2014. - No. 4. - pp. 137-142.

\section{Authors:}

Agoshkov Valery Ivanovich, Principal Researcher of the Institute of Numerical Mathematics of the Russian Academy of Sciences (Gubkin St. 8, Moscow, Russian Federation), Professor of the Lomonosov Moscow State University (Leninskie Gory 1, Moscow, Russian Federation), Professor, Doctor of Sciences in Physics and Mathematics, Honored Scientist of the Russian Federation.

Sheloput Tatiana Olegovna, graduate student of the Institute of Numerical Mathematics of the Russian Academy of Sciences (Gubkin St. 8, Moscow, Russian Federation). 


\section{УДК 519.6}

\section{Вариационная ассимиляция данных о температуре для модели гидротермодинамики} Балтийского моря: решение проблемы открытых границ *

\section{В.И. Агошков ${ }^{* *}$, Т.О. Шелопут ${ }^{* * *}$}

Институт вычислительной математики РАH, Москва, Российская Федерация Московский государственный университет имени М. В. Ломоносова, Москва, Российская Федерация

В данной работе рассматривается задача моделирования акваторий с «жидкими» (открытыми) границами. Используется математическая модель циркуляции Балтийского моря, разработанная в ИВМ РАН. Модель основана на системе уравнений термогидродинамики в приближении Буссинеска и гидростатики. Для аппроксимации по времени используется метод расщепления. Для восстановления неизвестных функций в граничных условиях на открытых границах исследуется и решается задача ассимиляции температуры (солености). Для ускорения процедуры ассимиляции используется метод разделения областей.

Ключевые слова: вариационная ассимиляция данных; обратные задачи; открытые границы; численные методы; сопряженные уравнения

\section{Авторы:}

Агошков Валерий Иванович, главный научный сотрудник ИВМ РАН (119333, г. Москва, ул. Губкина, 8), профессор Московского государственного университета имени М. В. Ломоносова (119991, г. Москва, Ленинские горы, д. 1), профессор, доктор физико-математических наук, заслуженный деятель науки Российской Федерации.

Шелопут Татьяна Олеговна, аспирант ИВМ РАН (119333, г. Москва, ул. Губкина, 8).

\footnotetext{
* Работа выполнена при частичной поддержке РНФ (грант 14-11-00609, в рамках которого были проведены численные эксперименты) и РФФИ (грант 16-01-00548, в рамках которого проведено исследование сформулированных задач).

** E-mail: agoshkov@inm.ras.ru.

*** E-mail: sheloput@phystech.edu
} 